\title{
MULTI-MARKER STUDY OF THE RESPONSE OF BIVALVE MOLLUSK UNIO TUMIDUS INDUCED BY THE COMPOUNDS OF TYPICAL MUNICIPAL EFFLUENTS
}

\author{
L. L. Gnatyshyna ${ }^{1,2}$, H. I. Falfushynska ${ }^{1}$, V. V. Mykhalska ${ }^{1}$, \\ N. Y. Mischuk', O. B. Stoliar \\ ${ }^{1}$ Volodymyr Hnatyuk Ternopil National Pedagogical University \\ 2, Kryvonis St., Ternopil 46027, Ukraine \\ e-mail: Oksana.Stolyar@tnpu.edu.ua \\ ${ }^{2}$ I. Ya. Horbachevsky Ternopil State Medical University, 1, Maydan Voli, Ternopil 46001, Ukraine
}

The pharmaceutical and personal care products (PPCPs) became the most typical pollutants of the surface waters. The aim of this study was to evaluate the effects of the combine exposure to the common compounds of the municipal effluents, constituent of plastics bisphenol A (BPA) and popular medicine nifedipine (Nfd), on the model organism, a mussel Unio tumidus. Male $U$. tumidus were exposed for 14 days to the combination of $\mathrm{Nfd}(10 \mu \mathrm{M})$ and BPA $(0.88 \mathrm{nM})$. The indices of oxidative stress, metabolic, immune and endocrine activity, metal balance, as well as the manifestations of toxicity were detected. The exposure caused the features known for the effect of Nfd: the activation of the oxidative stress response, particularly $\mathrm{Cu}, \mathrm{Zn}$-superoxide dismutase (by 6.0 times), glutathione and oxyradical levels, metabolic shift to the anaerobiosis due to the elevated level of lactate in the digestive gland. The manifestation of endocrine disruption typical for the BPA effect - the increased level of alkali-labile phosphates (vitellogenin-like proteins) in gonads was detected. The caspase-3 related apoptotic activity was suppressed; whereas the cathepsin D mediated proteolysis and immune response of phenoloxidase were up-regulated significantly. The signs of geno-, neuro- and cytotoxicity were detected. These results detect that the approximation of the experimental conditions to the environmentally realistic situation could assist the comprehensive forecasting of the effects of utilized PPCPs for the aquatic animals.

Keywords: bisphenol A, nifedipine, combine exposure, endocrine disruption, oxidative stress, bivalve mollusk

\section{INTRODUCTION}

Contemporary environmental challenges are characterized by the combine effects of the different origin, the results of that could not be additive $[2,12,16]$. The desire to predict the response to this so called "concert effect" is clearly expressed in the contemporary approaches to evaluate the human health by 'exposome concept' [5]. 
However the analysis of the environmental impact on the aquatic animals is still based mostly on the experimental exposures to the separate effluents. Pharmaceutical and Personal Care Products (PPCPs) and their bioactive metabolites can be continually introduced to the aquatic environment via a number of routes, mainly from the municipal effluents, and need to be assessed as yet poorly understood contaminants even at low parts-per-trillion/parts-per-billion concentrations (ng- $\mu \mathrm{g} / \mathrm{L})$ [20]. They typically cannot be removed even by modern wastewater treatment plants [11]. Previously we studied the effect of typical PPCPs, calcium influx inhibitor nifedipine (Nfd), which is widely used as a cheap antianginal and antihypertensive medicine and is a common pollutant in the surface waters [13], and common product eluted from the polycarbonate plastics, Bisphenol A (BPA), recognized endocrine disruptor [4, 20], on the non-target organism, bivalve mollusk [6, 9]. Ca-channel blocker Nfd affected intracellular Zn distribution with the prominent elevation of its binding with metallothioneins and caused reductive stress indicated by elevated levels of reduced glutathione levels and an increase in lactate/ pyruvate ratio [9]. The exposure to BPA activated the vitellogenesis in male specimens, decreased the level of glutathione and lactate/pyruvate ratio [6]. The aim of the present study was to elucidate the combine effect of these two substances which act on the mollusks in opposite direction. For that we applied the multi-marker approach with the utilization of approved biomarkers of oxidative stress, metabolic, immune and endocrine activity, metal balance, as well as the manifestations of toxicity [19].

\section{MATERIALS AND METHODS}

Adult male Unio tumidus (Unionidae) $(8 \pm 1 \mathrm{~cm}$ length, and $42 \pm 5 \mathrm{~g}$ weight) were collected in early autumn from 0.5 to $1 \mathrm{~m}$ depth in a pristine site in the river Dniester basin and transported to the laboratory. One group was exposed to the tap water only and was considered control, another group was exposed to BPA (0.88 nM) and nifedipine $(\mathrm{Nfd}, 10 \mu \mathrm{M})$,) during 14 days with the replacing of water medium each two days. No mortality of mussels was detected during the experimental exposure. After exposure, mollusks were immediately dissected on ice. Lysosomal membrane stability and the nuclear abnormalities were determined in hemocytes, alkali-labile phosphates (ALP) in hemolymph and gonads and all other markers - in the digestive gland. Tissue were sampled at $4{ }^{\circ} \mathrm{C}$, and hemocytes were studied immediately after sampling, while other tissues were frozen $\left(-40^{\circ} \mathrm{C}\right)$ until further analyses. Hemolymph was withdrawn from the adductor muscle sinus using a hypodermic syringe that contained $200 \mu \mathrm{L}$ of phosphatebuffered saline ( $\mathrm{pH}$ 7.4). The sample was then held on ice. Hemocytes were pelleted at $250 \times g$, resuspended in phosphate-buffered saline /EDTA (v/v 1:1), diluted to a density of $4 \times 10^{6}$ cells $/ \mathrm{mL}$, then aliquoted to analysis

For enzymatic analyses, tissue samples were homogenized $(1 / 10 \mathrm{w} / \mathrm{v})$ in $0.1 \mathrm{M}$ phosphate buffer, pH 7.4, containing $100 \mathrm{mM} \mathrm{KCl}$ and $1 \mathrm{mM}$ EDTA, as well as $0.1 \mathrm{mM}$ phenylmethylsulfonyl fluoride (PMSF) to inhibit proteolysis. Homogenates were centrifuged for $10 \mathrm{~min}$ at $6,000 \mathrm{~g}$, Protein concentration in the supernatant was measured by the method of Lowry et al. [14], using bovine serum albumin as the protein standard.

The activities of superoxide dismutase (Mn- and Cu, Zn-SOD, EC 1.15.1.1) and cholinesterase (ChE, EC 3.1.1.7), levels of cellular thiols glutathione (GSH and GSSG) and metallothionein, protein carbonyls, lactate and pyruvate were determined in digestive gland by spectrophotometric methods, and Cytochrome P450 monooxygenase (CYP450) activity as microsomal ethoxyresorufin-O-deethylase (EROD) activity,

ISSN 1996-4536 (print) • ISSN 2311-0783 (on-line) • Біологічні Студії / Studia Biologica • 2017 • Том 11/№2 • С. 37-44 
oxyradicals, lipofuscin and DNA strand breaks in digestive gland - by fluorescence methods that were described in details in [7-9]. The phenoloxidase-like activity (PhO, EC 1.14.18.1) was determined in the digestive gland spectrophotometrically by recording the formation of o-quinones [15]. Level of alkali-labile phosphates (ALP) was determined in hemolymph and gonads as indirect characteristic of the vitellogenin $(\mathrm{Vtg})$ concentration as it was described in [8, 9]. Activity of caspase-3 and cathepsin D (total and free) (a markers of apoptosis) was assayed colorimetrically. Cytotoxicity was evaluated as the time of the lysosomal membrane stability from Neutral Red Retention (NRR) assay [19]. Genotoxic effect was also assessed in the hemocytes by the frequency of the cells with micronuclei (MN) and other abnormalities [3].

Metals zinc $(\mathrm{Zn})$, copper $(\mathrm{Cu})$ and cadmium $(\mathrm{Cd})$ content was evaluated in the digestive gland and metallothionein-contained fraction of thermostable proteins of digestive gland by the atomic absorption spectrophotometry. Thermostable proteins were obtained by size-exclusion chromatography on Sephadex G-50 as it was described in [9]. For the isolation, tissue samples from five individuals of specific experimental group were pooled in aliquot quality (total mass $350 \mathrm{mg}$ ). For all traits and all experimental treatment groups, sample size was 8 . Only exception was for the metal concentration in the metallothioneins that was determined in triplicate. The data are presented as $\mathrm{M} \pm \mathrm{SD}$. All statistical calculations were performed with Statistica v. 10.0. Differences were considered significant if the probability of Type I error was $<0.05$.

\section{RESULTS AND DISCUSSION}

The evaluation of the state of the oxidative stress response has shown its prominent activation, particularly of Cu,Zn-SOD (by 6.0 times) and increase of RI GSH. The level of the oxyradical formation and the products of oxidative lesions, lipofuscin and protein carbonyls, was also elevated (by 206, 19 and $37 \%$ correspondingly). That attests the equilibrated in general antioxidant response. The similar antioxidant activation was also shown for the effect of Nfd on the mussel [9] and in marsh frog [7], whereas BPA caused the down-regulation of antioxidant response [6]. The level of stress-responsive protein metallothionein in the combine exposure was decreased (by $22 \%$ ), in opposite to the effect of Nfd alone on the mollusk [9] and frog [7]. The ability to decrease the expression of metallothionein gene was shown earlier for the endocrine disruptors of different nature, including BPA, in fish independently on the gender [18].

The metabolic response of the mussels to combine exposure was characterized by the prominent anaerobic shift with the elevation of lactate level and Lactate/Piruvate ratio more than two times (Table 1 ). Similar response of mussels was caused by Nfd alone but was not shown for the BPA [6, 9].

The level of metals in the tissue of digestive gland was characterized by the overaccumulation of $\mathrm{Cu}$ and $\mathrm{Cd}$ but decrease of the level of $\mathrm{Zn}$ in the tissue (Table 2). On the other hand, the metallothionein-related level of $\mathrm{Cu}$ and $\mathrm{Zn}$ was increased similarly as by Nfd alone [9], and Cd level in metallothioneins decreased (Table 2). Hence, despite the low part of metals in these proteins compare to metal concentration in the tissue and decrease in the total level of metallothionein, these proteins supplied the certain store of essential metals within the cells.

The evaluation of the cytotoxicity of the combine exposure (Table 3) demonstrated different signs of the lesions in all studied tissues. The level of lysosomal membrane stability (NRR time) was decreased till the critical level; depletion of cholinesterase at-

ISSN 1996-4536 (print) • ISSN 2311-0783 (on-line) • Біологічні Студії / Studia Biologica • 2017 • Том 11/№2 • C. 37-44 
tested the neurotoxicity, known for the effect of BPA on different animal models [17]. The absence of the neurotoxic effect of BPA in the presence of $\mathrm{Nfd}$ as L-type $\mathrm{Ca}^{2+}$-channels antagonist was shown for the frog sciatic nerve [17] demonstrating the dependence of the BPA toxicity on these $\mathrm{Ca}^{2+}$-channels [17]. However, the evidence of other mechanisms of neurotoxicity in the co-exposure was evident from the depletion of ChE in the mussels in the present study.

Table 1. Responses to the co-exposure to bisphenol A and nifedipine of the parameters of stress and metabolic activity in the digestive gland of Unio tumidus, $\mathrm{M} \pm \mathrm{SD}$, $\mathrm{N}=8$

Таблиця 1. Реакція на спільну дію бісфенолу А та ніфедипіну параметрів стресу

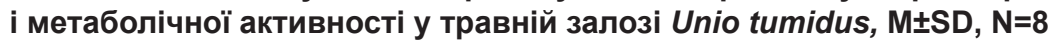

\begin{tabular}{|c|c|c|}
\hline Parameters & Control & Exposure \\
\hline Mn-SOD, RU·mg ${ }^{-1}$ protein & $2.7 \pm 0.3$ & $4.1 \pm 0.6^{*}$ \\
\hline $\mathrm{Cu}, \mathrm{Zn}-\mathrm{SOD}, \mathrm{RU} \cdot \mathrm{mg}^{-1}$ protein & $1.0 \pm 0.2$ & $6.0 \pm 0.9^{*}$ \\
\hline $\mathrm{GSH}, \mu \mathrm{mol} \cdot \mathrm{g}^{-1}$ of tissue & $1.45 \pm 0.10$ & $3.30 \pm 0.40^{*}$ \\
\hline GSSG, $\mathrm{nmol} \cdot \mathrm{g}^{-1}$ of tissue & $39.0 \pm 8.7$ & $41.8 \pm 9.3$ \\
\hline Redox Index (RI) of GSH, RU & $0.97 \pm 0.01$ & $0.99 \pm 0.01^{*}$ \\
\hline Oxyradical formation, RFU $\cdot \mathrm{g}^{-1}$ tissue & $3.6 \pm 0.4$ & $11.0 \pm 1.7^{*}$ \\
\hline Lipofuscin, RFU RFU· $\mathrm{g}^{-1}$ tissue & $67.2 \pm 2.2$ & $79.9 \pm 3.2^{*}$ \\
\hline Protein carbonyls, $\mathrm{nmol} \mathrm{mg}^{-1}$ protein & $17.3 \pm 1.9$ & $23.7 \pm 3.7^{*}$ \\
\hline Metallothionein, $\mu \mathrm{g} \cdot \mathrm{g}^{-1}$ tissue & $18.2 \pm 2.5$ & $14.2 \pm 1.7^{*}$ \\
\hline Lactate, $\mu \mathrm{mol} \cdot \mathrm{g}^{-1}$ tissue & $7.0 \pm 0.4$ & $16.4 \pm 1.9^{*}$ \\
\hline Piruvate, $\mu \mathrm{mol} \cdot \mathrm{g}^{-1}$ tissue & $2.4 \pm 0.3$ & $2.6 \pm 0.2$ \\
\hline Lactate/Piruvate ratio, $\mathrm{RU}$ & $3.0 \pm 0.3$ & $6.7 \pm 0.7^{*}$ \\
\hline
\end{tabular}

Comment: here and in the Tables 2, 3, asterisks indicate the values of the traits that significantly differ between control and exposed mussels $(P<0.05)$

Примітка: тут і в табл. 2, 3, зірочками позначені показники, які вірогідно різняться у контрольних та експонованих молюсків $(P<0,05)$

Table 2. Concentration of metals in the digestive gland and its metallothioneins (MT) of Unio tumidus under the co-exposure to bisphenol $A$ and nifedipine, $M \pm S D, N=8$ for the concentration in the tissue and $\mathrm{N}=3$ for the concentration in metallothioneins

Таблиця 2. Концентрація металів у травній залозі та їі металотіонеїнах (MT) Unio tumidus за спільної дії бісфенолу А та ніфедипіну, M $\pm S D, N=8$ для концентрації у тканині та $\mathrm{N}=3$ для концентрації у металотіонеїнах

\begin{tabular}{|l|c|c|}
\hline \multicolumn{1}{|c|}{ Parameters } & Control & Exposure \\
\hline $\mathrm{Cu} \mu \mathrm{g} \cdot \mathrm{g}^{-1}$ tissue & $2.0 \pm 0.2$ & $4.9 \pm 0.5^{*}$ \\
\hline $\mathrm{Zn}, \mu \mathrm{g} \cdot \mathrm{g}^{-1}$ tissue & $97.4 \pm 9.1$ & $74.4 \pm 4.9^{*}$ \\
\hline $\mathrm{Cd}, \mu \mathrm{g} \cdot \mathrm{g}^{-1}$ tissue & $2.9 \pm 0.3$ & $4.0 \pm 0.2^{*}$ \\
\hline $\mathrm{Cu}-\mathrm{MT}, \mu \mathrm{g} \cdot \mathrm{g}^{-1}$ tissue & $0.08 \pm 0.01$ & $0.42 \pm 0.06^{*}$ \\
\hline $\mathrm{Zn}-\mathrm{MT}, \mu \mathrm{g} \cdot \mathrm{g}^{-1}$ tissue & $2.0 \pm 0.2$ & $2.5 \pm 0.2^{*}$ \\
\hline $\mathrm{Cd}-\mathrm{MT}, \mu \mathrm{g} \cdot \mathrm{g}^{-1}$ tissue & $0.10 \pm 0.01$ & $0.07 \pm 0.01^{*}$ \\
\hline
\end{tabular}

ISSN 1996-4536 (print) • ISSN 2311-0783 (on-line) • Біологічні Студії / Studia Biologica • 2017 • Том 11/№2 • С. 37-44 
Besides, the signs of genotoxicity were detected both in the digestive gland and hemocytes (Table 3). However, the caspase-3 related way of apoptosis was oppressed prominently (by 2.3 times). On the other hand, the lysosomal peptidase cathepsin D was highly activated, and its efflux from the lysosomes attested the destroying of these organelles. Correspondingly, the exposure caused more likely the events of necrosis then apoptotic depletion of the injured cells. This statement is supported by the results of the activation of immune response, whereas the PhO activity was elevated by 2.7 times. Interestingly, the PhO activity in the presence of CTAB (specific laccase inhibitor, cethyltrimethylammonium bromide) was significantly oppressed demonstrating that laccase represents the main sub-class of $\mathrm{PhO}$ oxido-reductase activity in the digestive gland of $U$. tumidus. Moreover, exposure caused significant oppression of the oxido-reductive activities that are not related to laccase ((i.e. tyrosinase, catecholase [15]) and activation of laccase in the mussels. This response was opposite to the oppression of $\mathrm{PhO}$ activity by BPA alone [6]. Different studies have shown a strong correlation between the decrease in PhO activities and the occurrence of diseases in bivalve mollusks [15]. We speculate that in the combine exposure the Nfd was responsible for the activation of different antioxidants including the PhO-like activities in the exposed mussels.

Table 3. Biomarkers of toxicity in the digestive gland (DG), hemocytes (H) hemolymh $(\mathrm{HL})$ and gonads (G) of Unio tumidus, exposed to combination of bisphenol A and nifedipine, $\mathrm{M} \pm \mathrm{SD}, \mathrm{N}=8$

Таблиця 3. Біомаркери токсичності у травній залозі (DG), гемоцитах (H), гемолімфі (HL) та гонадах (G) Unio tumidus за спільної дії бісфенолу А та ніфедипіну, $\mathrm{M} \pm \mathrm{SD}, \mathrm{N}=\mathbf{8}$

\begin{tabular}{|c|c|c|}
\hline Parameters & Control & Exposure \\
\hline Neutral Red Retention (NRR) time, $\mathrm{H}$, min & $35 \pm 5$ & $25 \pm 3^{*}$ \\
\hline Cholinesterase, DG, $\mathrm{nmol} \cdot \mathrm{min}^{-1} \mathrm{mg}^{-1}$ proteins & $2.8 \pm 0.3$ & $1.8 \pm 0.3^{*}$ \\
\hline DNA strand-break, DG, \% & $6.7 \pm 0.7$ & $7.7 \pm 0.3^{*}$ \\
\hline Hemocytes with micronuclei, \% & $1.5 \pm 0.3$ & $3.5 \pm 0.4^{*}$ \\
\hline Hemocytes with other abnornalities, $\%$ & $7.0 \pm 0.8$ & $11.0 \pm 1.3^{*}$ \\
\hline Caspase-3, DG, $\mathrm{pmol} \cdot \mathrm{min}^{-1} \cdot \mathrm{mg}^{-1}$ proteins & $75.9 \pm 10.7$ & $33.5 \pm 9.9^{*}$ \\
\hline Cathepsine D free activity, DG, pmole min $^{-1} \mathrm{mg}^{-1}$ protein & $0.32 \pm 0.07$ & $0.63 \pm 0.09^{*}$ \\
\hline Cathepsine D total activity, DG, pmole $\mathrm{min}^{-1} \mathrm{mg}^{-1}$ protein & $0.64 \pm 0.09$ & $1.78 \pm 0.25^{*}$ \\
\hline 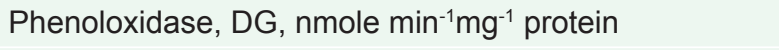 & $24.2 \pm 2.5$ & $64.3 \pm 12.1^{*}$ \\
\hline Phenoloxidase + CTAB, DG, $\mathrm{nmol} \mathrm{min} \mathrm{mg}^{-1} \mathrm{mp}^{-1}$ rotein & $6.0 \pm 0.9$ & $1.7 \pm 0.4^{*}$ \\
\hline EROD, DG, pmol min $\mathrm{mg}^{-1} \mathrm{mg}^{-1}$ proteins & $2.9 \pm 0.1$ & $6.9 \pm 0.2^{*}$ \\
\hline Alkali-labile phospate, $\mathrm{G}, \mu \mathrm{g} \mathrm{P}_{\mathrm{i}} \cdot \mathrm{mg}^{-1}$ proteins & $10.0 \pm 1.1$ & $45.7 \pm 10.5^{*}$ \\
\hline Alkali-labile phospate, $\mathrm{HL}, \mu \mathrm{g} \mathrm{P}_{\mathrm{i}} \cdot \mathrm{mg}^{-1}$ proteins & $2.9 \pm 0.1$ & $2.5 \pm 0.7$ \\
\hline
\end{tabular}

The activation of EROD demonstrates the involving of CYP450-related oxidation in the transformation of the applied substances in the digestive gland of mussels (Table 3 ). This response is typical for the exposures to the persistent organic pollutants and serves as a biomarker of the pollution by these substances [19]. It was shown for the effect of BPA alone [6]. 
The major injury known for BPA is the endocrine disruption $[4,17]$. The evaluation of the ALP detected this typical effect - the increase of the level of these vitellogenin-like proteins in the gonads of male specimens, despite in the hemolymph their level was not changed by exposure. The endocrine disruptive effects of BPA were shown earlier in marine mussels affecting significantly their reproduction [1, 4].

The diversity of the cellular responses of the freshwater mussels to different PPCPs and sometimes opposite manifestations was demonstrated earlier [6, 9, 10]. The results of the combine exposure reflected the typical responses to both substances - the antioxidant activation and metabolic shift caused by Nfd and endocrine disruption, metallothionein and cholinesterase depletion as the response to BPA. The activation of PhO could be regarded as the up-regulation of immune-responsive antioxidants, whereas its oppression was reported for the inflectional diseases of mussels [15]. Nevertheless, the plural signs of toxicity demonstrated that the combine exposure doesn't leveling the adverse effect of BPA. Moreover, the utilized in the present study concentration of BPA was corresponding to the reported level in the surface and ground waters (600-900 ng L $\mathrm{L}^{-1}$ ) (cited from [1]).

\section{CONCLUSION AND PERSPECTIVES}

The applying of multi-marker approach demonstrated the adverse effect of the co-exposure to BPA and Nfd. Despite the activation of adaptive responses of oxidative stress and metabolic shift typical for $\mathrm{Nfd}$, the final consequences of cytotoxicity and endocrine disruption caused by BPA were prominent. These results detect that the approximation of the experimental conditions to the environmentally realistic situation could assist the comprehensive forecasting of the effects of utilized PPCPs for the aquatic animals corresponding to the 'exposome' approach.

\section{ACKNOWLEDGMENTS}

This work has been granted by the Ministry of Education and Science of Ukraine (Projects \#\# 125B; M/70-2017).

1. Aarab N., Lemaire-Gony S., Unruh E. et al. Preliminary study of responses in mussel (Mytilus edilus) exposed to bisphenol A, diallyl phthalate and tetrabromodiphenyl ether. Aquatic Toxicology, 2006; 78: S86-S92.

2. Amin M.T., Alazba A.A., Manzoor U. A Review of Removal of Pollutants from Water/Wastewater Using Different Types of Nanomaterials. Advances in Materials Science and Engineering, 2014.

3. Baršiené J., Rybakovas A. Cytogenetic damage in gill and gonad cells of bivalve mollusks. Ekologija, 2008; 54(4): 245-250.

4. Canesi L., Borghi C., Ciacci C. et al. Bisphenol-A alters gene expression and functional parameters in molluscan hepatopancreas. Molecular and Cellular Endocrinolology, 2007; 276: 36-44.

5. Escher B.I., Hackermüller J., Polte T. et al. From the exposome to mechanistic understanding of chemical-induced adverse effects. Environmental International, 2017; 99: 97-106.

6. Falfushynska H., Gnatyshyna L., Horyn O., Stoliar O. Effects of $\mathrm{n}-\mathrm{TiO}_{2}$ and bisphenol A on cellular stress indices of the freshwater bivalve Unio tumidus. Visnyk of the Lviv University. Biology Series, 2016. 73: 208-212.

7. Falfushynska H., Gnatyshyna L., Horyn O. et al. Endocrine and cellular stress effects of zinc oxide nanoparticles and nifedipine in marsh frogs Pelophylax ridibundus. Aquatic Toxicology, 2017; 185: 171-182.

ISSN 1996-4536 (print) • ISSN 2311-0783 (on-line) • Біологічні Студії / Studia Biologica • 2017 • Том 11/№2 • С. 37-44 
8. Falfushynska H., Gnatyshyna L., Yurchak I. et al. Habitat pollution and thermal regime modify molecular stress responses to elevated temperature in freshwater mussels (Anodonta anatina: Unionidae). Science of the Total Environment, 2014; 500-501: 339-350.

9. Falfushynska H., Gnatyshyna L., Yurchak I. et al. The effects of zinc nanooxide on cellular stress responses of the freshwater mussels Unio tumidus are modulated by elevated temperature and organic pollutants. Aquatic Toxicology, 2015; 162: 82-93.

10. Falfushynska H.I., Gnatyshyna L.L., Osadchuk O.Y. et al. Diversity of the molecular responses to separate wastewater effluents in freshwater mussels. Comparative Biochemistry and Physiology, 2014; 164: 51-58.

11. Fent K., Weston A.A., Caminada D. Ecotoxicology of human pharmaceuticals. Aquatic Toxicology, 2006; 76: 122-159.

12. Hrubik J., Glisic B., Tubic A. et al. Toxicological and chemical investigation of untreated municipal wastewater: Fraction-and species-specific toxicity. Ecotoxicology and Environmental Safety, 2016; 127: 153-162.

13. Kolpin D.W., Furlong E.T., Meyer M.T. et al. Pharmaceuticals, hormones, and other organic wastewater contaminants in U. S. streams, 999-2000: a national reconnaissance. Environmental Science \& Technology. 2002; 36(6): 1202-1211.

14. Lowry O.H., Rosebroungh H.J., Farr A.L., Randall R.J. Protein measurement with folin phenol reagent. Journal of Biological Chemistry 1951; 193: 265-275.

15. Luna-Acosta A., Breitwieser M., Renault T., Thomas-Guyon H. Recent findings on phenoloxidases in bivalves. Marine Pollution Bulletin, 2017; 122(1-2): 5-16.

16. Noyes P.D., Lema S.C. Forecasting the impacts of chemical pollution and climate change interactions on the health of wildlife. Current Zoology, 2015; 61(4): 669-689

17. Pandey A.K., Deshpande S.B. Bisphenol A depresses compound action potential of frog sciatic nerve in vitro involving $\mathrm{Ca}(2+)$-dependent mechanisms. Neuroscience Letters, 2012; 517(2):128-132.

18. Rhee J.S., Raisuddin S., Hwang D.S. et al. Differential expression of metallothionein (MT) gene by trace metals and endocrine-disrupting chemicals in the hermaphroditic mangrove killifish, Kryptolebias marmoratus. Ecotoxicology and Environmental Safety, 2009, 72(1): 206-212.

19. Viarengo A., Lowe D., Bolognesi $C$. et al. The use of biomarkers in biomonitoring: a 2-tier approach assessing the level of pollutant-induced stress syndrome in sentinel organisms. Comparative Biochemistry and Physiology, 2007, 146C: 281-300.

20. Wagner M., Oehlmann J. Endocrine disruptors in bottled mineral water: total estrogenic burden and migration from plastic bottles. Environmental Science and Pollution Research, 2009, 16: 278-286.

\title{
МУЛЬТИМАРКЕРНЕ ДОСЛІДЖЕННЯ РЕАКЦІЇ ДВОСТУЛКОВОГО МОЛЮСКА UNIO TUMIDUS HА ДIЮ ТИПОВИХ СКЛАДОВИХ МУНІЦИПАЛЬНИХ СТОКІВ
}

\author{
Л. Л. Гнатишина ${ }^{1,2}$, Г. І. Фальфушинська ${ }^{1}$ В. В. Михальська", \\ Н. Й. Міщук', О. Б. Столяр ${ }^{1}$ \\ ${ }^{1}$ Тернопільський національний педагогічний університет імені Володимира Гнатюка \\ вул. М. Кривоноса, 2, Тернопіль 46027, Україна \\ e-mail: Oksana.Stolyar@gmail.com \\ ${ }^{2}$ Тернопільський державний медичний університет імені І.Я. Горбачевського \\ Майдан Волі, 1, Тернопіль 46001, Україна
}

Продукти фрармацевтики й особистого вжитку (ПФОВ) набувають статусу найтиповіших забруднювачів поверхневих вод. Метою цього дослідження було 
оцінити вплив спільної дії типових складових муніципальних стоків, компонента пластику бісфенолу А (БФА) та популярного лікарського препарату ніфедипіну (Нфд) на модельний організм двостулкового молюска Unio tumidus. Особини чоловічої статі U. tumidus піддавали протягом 14 діб спільній дії Нфд (10 мкМ) та БФА (0,88 нМ). Визначали показники окисного стресу, метаболізму, імунної та ендокринної активності, балансу металів, а також прояви токсичності. У дослідних тварин спостерігали ознаки, відомі для дії Нфд: посилення реакції окисного стресу,

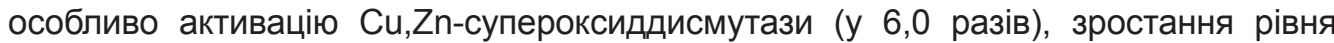
глутатіону й оксирадикалів, а також метаболічне зміщення в бік анаеробіозу згідно зі зростанням рівня лактату у травній залозі. Було відзначено прояви ендокринних розладів, притаманних дії БФА, підвищений рівень лужно-лабільних фоосфатів (вітелогенін-подібних протеїнів) у гонадах. Апоптична активність, опосередкована каспазою-3, булапригнічена, тодіякпротеоліз за участю катепсинуДта імунна реакція фенолоксидази були суттєво активовані. Відзначено також ознаки гено-, нейроі цитотоксичності. Ці результати доводять, що наближення експериментальних умов до реалістичної ситуації у довкіллі буде сприяти об'єктивному прогнозу наслідків впливу ПФОВ на водяних тварин.

Ключові слова: бісфенол А, ніфедипін, поєднана дія, ендокринний розлад, окисний стрес, двостулковий молюск

Одержано: 11.09.2017

ISSN 1996-4536 (print) • ISSN 2311-0783 (on-line) • Біологічні Студії / Studia Biologica • 2017 • Том 11/№2 • С. 37-44 